\title{
The PASS Processing Development and its Relationship to Mathematical Competency (Neuropsychological Assessment)
}

\author{
Suzanne M. I. Arafa, Assistant Lecturer of Educational \\ Psychology \\ Faculty of Education, Helwan University
}

\section{Prof Amal A. M. Sadek, Emeritus Professor of Educational Psychology Prof Mohamed A.K. Abdel Ghafar, Emeritus Professor of Educational Psychology}

\begin{abstract}
Tracing the connection from brain functions to children's development and education is a major goal of modern human neuroscience. This study examined age-related changes in complex PASS neurocognitive functions in a representative sample $(N=450)$ aged 8 to 17 , using the Cognitive Assessment System (CAS; Naglieri \& Das, 1997a). The development of the relations between complex PASS functions and mathematical competence were examined given the mathematics competency battery (Vernon, Miller,and Izard, 2013).

Manova, Anova and correlational analysis were used to analyze the data. Manova analysis revealed that performance on PASS functions improved until late adolescence although, improvement slowed with increasing age; but never improved on attention after age 13. Moreover, Anova analysis showed that the performance on mathematical competence appears to develop until age 14 with less rapid improvement at the older ages.

Correlational analysis indicated that, from age (8 to 11) attention and simultaneous processing are strong related to math competence with moderate relation to successive processing; while from age (11 to 13), high correlation between simultaneous processing and planning with mathmatical competency and more moderate with attention, and from age (14 to 17), planning and simultaneous processing is strong related to math competence with moderate relation to attention. These results show that, simultaneous processing are strongly related to mathematical competence development for all age groups.

Training programs based on PASS processing and modification of mathematical curriculum should take place from childhood in order to improve acquiring a sufficient mathematical competencies as crucial outcomes, which develop their motivational orientations.
\end{abstract}

Key words: Neurocognitive Development,PASSTheory ,MathematicalCompetency,Cognitive Assessment System ,Childhood ,Adolescence. 


\title{
The PASS Processing Development and its Relationship to Mathematical Competency (Neuropsychological Assessment)
}

\author{
Suzanne M. I. Arafa, Assistant Lecturer of Educational \\ Psychology \\ Faculty of Education, Helwan University
}

\section{Prof Amal A. M. Sadek, Emeritus Professor of Educational Psychology Prof Mohamed A.K. Abdel Ghafar, Emeritus Professor of Educational Psychology}

\section{Introduction}

Mathematical competence is one of the key cognitive abilities that is acquired through formal schooling. In general, it is a central component of human intelligence and thus highly relevant for educational and occupational attainment. To master mathematics means to possess Mathematical Competence, but then, what does it mean?

The programme for International Student Assessment (PISA, 2000) explains that, the term competence is used to indicate the ability to put mathematical knowledge and skill to functional use rather than just to master it within a school curriculum (OECD, 2000) $)^{1}$.It is not linked to a curriculum in the traditional sense of a study programme (Rico, 2006).A broader definition of competence, however, is one that recognizes that performance is underpinned not only by a skill such completing addition, sums, and solving routine problems but also by making a productive use for knowledge which involves both the ability to perform in a given context and the capacity to transfer knowledge and skills to new tasks and situations (Mayer, 1992). Mathematical Competence then means as the ability to understand, judge, do and use mathematics in a variety of intra and extra-mathematical contexts and situations in which mathematics plays or could play a role (Niss, 2003). According to our research, Mathematical Competence is defined as a cognitive processes which should be activated to connect the real world in which the problem arises with mathematics and solve the problem posed.

Organisation for Economic Co-operation and Development (OECD). (2000). ${ }^{1}$ Measuring student knowledge and skills: The PISA 2000 Assessment of reading, mathematical and scientific literacy. Paris: PISA, OECD Publishing. doi: 10.1787/9789264181564-en.

=|(2)= الدجلة المصرية للاراسات النفسية - العدد92 المجلد السادس والعشرون - يولية 2016 ســ 
Recently, diverse investigations have focused on understanding the functioning of the underlying cognitive processes and their mediating role in mathematical competency, which we have assumed in this study, e.g. (SotoCalvo, et al., 2015).It investigates the extent to which phonological, visualspatial, short term memory and non-symbolic, quantitative skills support the development of counting and calculation competencies through a longitudinal study. It reveals that the development of math competency for 125 children are supported by different cognitive abilities. Also, (Krajewski\& Schneider, 2009) explored, the impact of phonological awareness and visual spatial working memory assessed at 5 years; was mediated by early quantity number competencies which predicted math processing in third grade and found a moderate relationship between early literacy and mathematical competencies development. From this position. We aim to identify the cognitive predictors based on PASS Theory and its relationship with mathematical competence over a wide age range ( 8 to 17$)$ years with representative sample $(N=450)$.

Recently, one area has received more intense focus in the study of cognition has been the development of neurocognitive functioning in children and adolescents which emerged as the investigation of brain-behaviour relation concerning age-related changes in knowledge and acts of knowing. Although, many advances have emerged in imaging techniques; neuropsychological tests continue to play an important role in identifying the cognitive processes or abilities necessary for effective thinking, learning and behaving, while also allowing for judgments regarding the integrity of the brain (Riccio, Sullivan \& Cohen, 2010)

The Cognitive Assessment System (CAS) (Naglieri \& Das, 1997) is a multidimensional measure of ability based on neuropsychological processing theory called Planning, Attention, Simultaneous and Successive Processing (PASS) (Naglieri, 2005). The battery was developed to be used whenever it is important to determine an individual's competence and levels of cognitive functioning which will be suitable for the purpose of our study; so that the examiner may be informed about (a) the relative levels of Processing (strengths and weakness) within the individual, (b) the competence of processing in relation to peers, (c) the relationships between PASS Processing Scores and Achievement, and (d)the implications this information has for the child. Many studies embracing PASS revealed that uses of CAS which included diagnosis of learning strength and weakness; classification (learning disabilities, attention deficit, mental retardation, giftedness); eligibility decisions (meeting state or federal criteria), and consideration of the appropriateness of particular treatment, instructional, or remedial programs. (Naglieri,\& Das, (1997); Kirby \& Williams, (1991); Naglieri,

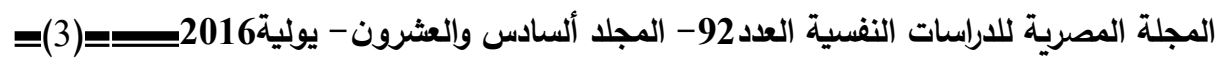


2000; Eldeeb,A.,2001; Rasha,M.,2002; Eladl,2000; Riad,1997)

They redefined intelligence as a function of four basic psychological processes that make up PASS theory represent a blend of cognitive and neuropsychological constructs. These mental functioning units are based on the work of Luria $(1966,1980)$ who established that human cognitive processing requires the cooperation of three functional systems that work together and whose participations is necessary for any type of mental activity (Luria, 1973).

The first functional unit, Selective Attention is responsible for regulating cortical tone and maintaining attention; the second unit, Execute functioning (Planning) receives, processes and stores information, encoding it Successively and Simultaneously; the third unit, programs, regulates and directs mental activity with these origins in neuropsychology. Das and colleagues elaborated a theory of Cognitive Processing (Das et al., 1994).

According to these theory Naglieri \& Das, Planning is associated with the prefrontal cortex which plays a central role in forming goals and objectives and then in devising plans of action required to attain these goals. It selects the cognitive skills required to implement the plans, coordinates these skills and applies them in a correct order. It helps by self-regulating their performance to achieve the desired goals and aiding in the development of strategies needed to accomplish tasks. Therefore, Planning is essential to all activities that require one to figure out how to solve a problem, including self-monitoring and impulse control, as well as creation assessment, discriminating use of knowledge and skills and execution of a plan. (Goldberg, 2001)

The process of Attention supported by Luria's first functional unit, allows individuals to perform a focalized cognitive activity; selective and sustained over time, focusing on some stimuli and inhibiting others depending on the goals pursued (Das, et al., 1994). To deal with incoming information, individuals use two cognitive processes: Simultaneous processing is a mental activity by which they integrate stimuli into a perceptive or conceptual whole. It has a strong spatial and logical-grammatical components, and Successive processing by which they integrate stimuli into a specific serial order forming a chain-like progression (Naglieri \& Das, 1997). It is needed when things must follow each other in a strictly defined order (Eladl, 2000)

Finally, The Neuropsychology view of intelligence of PASS theory is different from the psychometric view; in that, it attempts to resolve how the mind works, anchoring its function in the brain and discriminating dysfunctions, individual differences and disabilities (Das \& Naglieri,

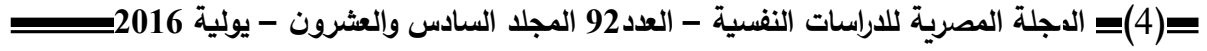


2001).Fadia Elwan $(1998,20)$ adds that Luria's study of neuropsychology points out "that the brain consists of different areas or section. Each area is specialized to carry out a particular role, and they are also reliant on the efficient functioning of other parts of the brain when performing a certain procedure. These processes can be easily affected by personal events, stress or any personal changes during the integration processes."

The PASS theory have been empirically related in diverse populations to measures of mathematical achievement, Simultaneous and Successive processing (e.g. Kroesbergen et al., 2003, Naglieri \& Das, 1987) Planning (Kirby \& Ashman, 1984; Joseph \& Hunter, 2001) and Attention (Kroesbergen et al., 2003).

Following a developmental studies, (Naglieri \& Das 1987)found how Planning, Simultaneous, and Successive processing are related to mathematics achievement in $2^{\text {nd }}$ and $6^{\text {th }}$ grade. However, in $10^{\text {th }}$ grade Successive processing remained at a similar level to Simultaneous processing in relation to math achievement. While (Kroesbergen et al., 2010), in a study with Italian and German kindergarten children, revealed that Simultaneous processing at early ages is more related to Piaget-tasks whereas Planning is more related to counting tasks. From this perspective. We aim to trace the progression of complex PASS processing and Mathematical Competence development across middle childhood and adolescence, documenting the magnitude of change during different age groups, using nearly identical tasks employed across the sample. The second aim is to determine the relationship between the PASS functioning and Mathematical Competency over a wide range (8 to 17$)$ in a representation Egyptian sample $(N=450)$.

\section{Problem of Study}

The problem of this research can be stated in the following questions:

1. What is the pattern of improvement in PASS processing with increasing age?

2. What is the pattern of improvement in mathematical competence with increasing age?

3. How are PASS functioning and mathematical competency related at each age group?

\section{Significance of the Study}

1. Studying the qualitative and quantitative changes across a different age range, coupled with continued development of valid and reliable PASS tasks; which may benefit attempts to remediate problems that not only limit children's mathematical development, but also other

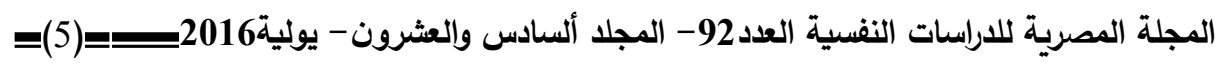


functional outcome.

2. Trace Progression for the rates of achieving performance for Egyptian students in international tests for measuring Mathematical Competency has been addressed and it's relation to complex PASS function development, which contribute to highlight on the shortcomings in the curriculum trying to be more adjusted for the needs of students.

3. PASS scales don't use achievement-like subtests (e.g., vocabulary and arithmetic) which would affect the correlation between tests of ability and achievement, as it will be more appropriate to measure Cognitive Processing with achievement laden tests for children with a history of school problems and especially for culturally and linguistically diverse populations.

\section{Method}

Design: Cross sectional design were used that allow us to describe age related differences in specific cognitive structure, estimating the continuity or discontinuity of various processes over age, that may affect the development of mathematical competence through formal schooling.

Participants: The pilot study, included a pilot sample included 750 participants, their age range from ( 8 to 17 ) years old, selected randomly from three different schools to determine the reliability and validity for the research's tools.

The final study, included children and adolescents $(\mathrm{N}=450)$ between the ages of 8 and 17 years. $(M=9.4$ years, $S D=3.2)$.

\section{Tools:}

\section{Cognitive Assessment System: Cognitive Processing}

The CAS is a standardized test that measures children's mental abilities as defined by the Planning, Attention, Simultaneous and Successive (PASS) theory of neuro cognitive functions (Das et al., 1994). The PASS theory, in turn, is based on the work of Luria, whose work linking brain anatomy and function informed much of neuropsychology (Luria, 1966).

Reliability of D: N: CAS for Egyptian sample (Alpha Coefficient) was calculated with split half method and corrected with Spearman Brown formula. The average internal reliability coefficient across all ages of sample $N=750$, for each one of the scales was (Planning) r=.92, (Attention) r=.90 (Successive) $r=.88$ and (Simultaneous) $r=.91$.

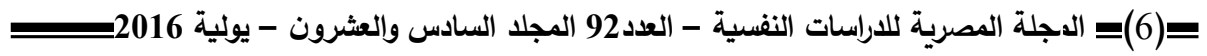


Validity: Construct validity was calculated with confirmatory factor analysis carried out separately in three age groups using Amos v23 (8 to 10, 11 to 13, and 14 to 17 years) on Egyptian sample, in order to assess the internal relationships among the observed variable. The findings of various goodness of fit and incremental indexes indicated a good correspondence.

\section{Planning}

Planning is a cognitive process by which the individual determines, selects, and uses a strategy or method to solve a problem efficiently. The planning process provides the means to solve problems for which no method or solution is immediately apparent. Planning is also important for impulse control as well as utilization of knowledge. The CAS Planning subtests require the application of strategies to perform the novel tasks presented.

Matching Numbers (MN) consists of four pages each consisting of eight rows of numbers with six numbers per row. Children are instructed to underline the two numbers in each row that are the same. Numbers increase in length across the four pages from one digit to seven digits with four rows for each digit length. Each item has a time limit. Children 5 to 7 years are administered Items 1 and 2, and children 8 through 17 Items 2 through 4 . The subtest score is based on the combination of time and number correct (accuracy score) for each page. Accuracy scores are summed and used as a measure of the child's efficiency. This subtest has an average internal reliability of .75 .

Planned Codes (PCd) contains two pages, each with a distinct set of codes and arrangement of rows and columns. A legend at the top of each page shows a correspondence of letters with codes (e.g., A, B, C, D to OX, XX, $\mathrm{OO}, \mathrm{XO}$, respectively). The page contains seven rows and eight columns of letters without codes. Children fill in the appropriate codes in empty boxes beneath each letter. On the first page, all the As appear in the first column, all the Bs in the second column, all the Cs in the third column, etc. On the second page, letters are configured in a diagonal pattern. The time and number correct (accuracy score) is combined for each page and these two scores are summed to obtain the raw score. This score is a measure of the child's efficiency. The average internal reliability is .82 .

Planned Connections contains eight items. The first six items require children to connect numbers appearing in a quasi-random order on a page in sequential order. The last two items require children to connect both numbers and letters in serial order alternating between numbers and letters (for example, 1-A-2-B-3-C). The items are constructed so that children never

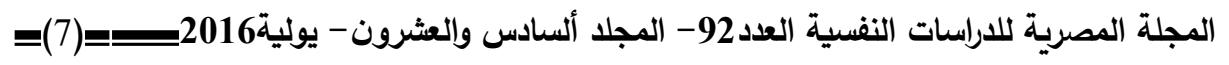


complete a sequence by crossing one line over the other. The time needed to complete the item sequence correctly is the best measure of efficiency, so the score is the total amount of time in seconds used to complete the items. The average internal reliability is .77 .

\section{Attention}

Attention is a cognitive process by which the individual selectively attends to a particular stimulus and inhibits attending to competing stimuli. Successful performance on the CAS Attention subtests requires attention to be focused, selective, sustained, and effortful. The tasks present competing demands on attention and require sustained focus over time to identify a target stimuli and avoid distractions.

Expressive Attention (EA) uses two different sets of items, depending on the age of the child, to measures selectivity and the ability to shift attention. The version for children 8 years and older is like the Stroop test. On the first page children read the color words (Blue, Yellow, Green, and Red) presented in quasi-random order. Next, they name the colors of a series of rectangles (printed in blue, yellow, green, and red). Finally, the words Blue, Yellow, Green, and Red are printed in a different color ink than the colors the words name. The child is instructed to name the color ink the word is printed in, rather than to read the word. For all subjects the last page only is used as the measure of attention. The raw score is the ratio of the accuracy (total number correct) and time. The average internal reliability of Expressive Attention is 80 .

Number Detection (ND) is comprised of pages of numbers that appear in different formats. On each page children are required to find a particular stimulus (the number 1, 2, and 3 printed in an open font) on a page containing many distracters (the same numbers printed in a different font style). There are 180 stimuli with 45 targets (25\% targets) on the pages. The raw score for Number Detection is the ratio of the accuracy (total number correct minus the number of false detections) and the total time for each item, summed across the items, is the raw score. The more accurate the child is at detecting the target stimuli and avoiding the distracting stimuli, the higher the score will be. The average internal reliability is .77 .

Receptive Attention (RA) is a two-page paper-and-pencil subtest. For children 8 years and above two pages are given. On the first page letters that are physically the same (for example, $\mathrm{T} \mathrm{T}$ but not $\mathrm{T} \mathrm{t}$ ) are targets, but on the second, letters that have the same name (for example, Aa not Ba) are targets. Each page contains 200 pairs of letters with 50 targets (25\% targets) and the same set of distracters. The raw score is the ratio of the accuracy (total

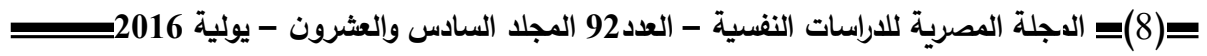


number correct minus the number of false detections) and the total time for each item. These scores are summed across the items to obtain a total raw score. The average internal reliability is .77 .

\section{Simultaneous}

Simultaneous processing involves integrating separate stimuli into a single whole or group. In addition to perceiving parts into a single gestalt, simultaneous processing requires understanding logical-grammatical relationships. Simultaneous subtests in the CAS require the child to perceive objects as a group and to interrelate separate elements into a whole through examination of the stimuli during the activity or through recall.

Nonverbal Matrices (NvM) is a 33-item multiple subtest that utilizes shapes and geometric designs that are interrelated through spatial or logical organization. Children are required to decode the relationships among the parts of the item and choose the best of six options. Each progressive matrix item is scored as correct or incorrect. The raw score is the total number of items correctly answered. The average internal reliability is .89 .

Verbal-Spatial Relations (VSR) is composed of 27 items that require the comprehension of logical and grammatical descriptions of spatial relationships. Children are shown items containing six drawings and a printed question at the bottom of each page. The items involve both objects and shapes that are arranged in a specific spatial manner. For example, the item "Which picture shows a circle to the left of a cross under a triangle above a square"? would include six drawings with various arrangements of geometric figures, only one of which matches the description. The examiner reads the question aloud and the child is required to select the option that matches the verbal description. Children must indicate their answer within the 30- second time limit to receive credit. The raw score is the total number of items correctly answered. The average internal reliability is .83 .

Figure Memory (FM) is a 27 -item subtest. Children are shown a two- or three- dimensional geometric figure for five seconds. The figure is then removed and the child is presented with a response page that contains the original design embedded in a larger, more complex geometric pattern. Children are asked to identify the original design embedded within the more complex figure. For a response to be scored correct, all lines of the design have to be indicated without any additions or omissions. The total number of correct items is the raw score. The average internal reliability is .89 .

\section{Successive}

Successive processing involves working with things in a specific serial order.

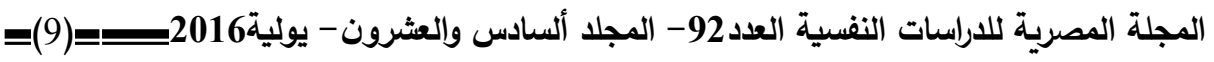


Perception of stimuli in sequence and the formation of sounds and movements in order are required in successive processing. The Successive subtests in the CAS require the child to either reproduce a sequence of independent stimuli or answer questions based on understanding of syntactic relationships.

Word Series (WS) requires the child repeat words in the same order as stated by the examiner. The test consists of the following nine single-syllable, highfrequency words: Book, Car, Cow, Dog, Girl, Key, Man, Shoe, Wall. There are 27 items which the examiner reads to the child. Each series ranges in length from two to nine words, presented at the rate of one word per second. Each item is scored as either correct if the child reproduces the entire word series in the order presented. The raw score is the total number of items correctly repeated. Word Series average internal reliability is .85 .

Sentence Repetition (SR) requires the child repeat 20 sentences that are read to the child. Each sentence is composed of color words (for example, "The blue is yellowing"). The children are required to repeat each sentence exactly as it was presented. Color words are utilized so that the sentences contain little meaning and help reduce the influence of simultaneous processing and accent the demands of the syntax of the sentence. Each item is scored as correct if the sentence is repeated exactly as presented. The raw score is the total number of sentences correctly repeated. The average internal reliability is .84 .

Sentence Questions (SQ) is a 21-item subtest that uses the same type of sentences as those in Sentence Repetition. Children (ages 8- 17 only) are read a sentence and then asked a question about the sentence. For example, the examiner says "The blue is yellowing" and asked the following question: "Who is yellowing?" (The answer is "The blue.") Successful completion of this task demands the comprehension of the sentence based on the serial placement of the words. Each item is scored as correct if the child successfully answers the question regarding the sentence. The raw score is the total number of questions answered correctly. The average internal reliability is .84 .

\section{Mathematics Competence Battery}

This battery was designed as a comprehensive instrument that provides detailed information about child's Mathematical Competence; through knowledge and skills that assess the student's ability to use mathematics in solving problems arising in authentic real world problems, rather than naming the topics studied in mathematic courses. In order to assess the progression; mathematical competencies (literacy) needs to be developed

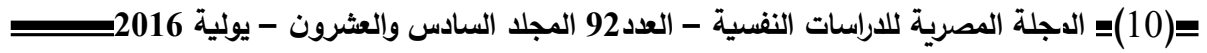


with students at different stages of the education system. We used the standardized score $(100,15)$ of the global scale as a descriptor of the student global mathematical performance, it is composed of two parts as follows:

\section{Part A: Graded Arithmetic Mathematics Test}

It is a standardized test for ages 5 to 11 administered to groups in about 30 minutes, starting from basic number knowledge. It comprises of 6-8 items open-ended per year group which sample a wide range of mathematical skills and gives a useful assessment of overall mathematical attainment.

The items were reviewed by experts of mathematic educators and math teachers; some modifications have been done for some items after Arabization applying the test on pilot sample. Their age range from 8 to 11 years, reliability was calculated with Alpha Coefficient for the test $r=.92$.

Validity: Using age discrimination validity were conducted by selecting 30 students from grades $(4,5,6)$ respectively. The results showed that the test discriminating the performance level between different grades.

\section{Part B: Mathematics competency test}

Written test suitable from age (12 - adult) assessing mathematics skills with 46 questions administrated in about 40 minutes. Open-ended questions require constructed responses which provide better evidence of student's capacity to undertake tasks than just recognition of a correct answer from a limited number of choices. The test comprised of four areas of mathematics as follows: Using and applying Mathematics, Number and algebra, Shape and space, and Handling data.

Reliability was calculated after Arabization and applying on pilot study using Alpha Coefficient $\mathrm{r}=.87$. Construct validity was calculated with maximum likelihood estimation and the analysis of principal components with Kaiser's orthogonal Varimax rotation. The final solution extracted 4 factors; using and applying mathematics, number and algebra, shape and space and handling data, which explained $50 \%$ of the total variance.

\section{Results:}

Table 1 Presents the means and standard deviations of the main results obtained by three different age groups in the proposed tests

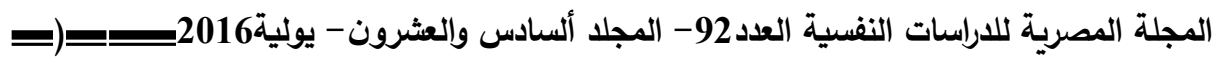


The PAss Processing Developmen and its Relationship Mathematical

\section{Descriptive Statistics}

\begin{tabular}{|c|r|r|r|r|r|r|r|r|r|r|r|}
\hline \multicolumn{2}{|c|}{} & \multicolumn{2}{|c|}{ PLANNING } & \multicolumn{2}{|r|}{ ATTENTION } & \multicolumn{2}{|r|}{$\begin{array}{r}\text { SUCCESIVE } \\
\text { PROCESS }\end{array}$} & $\begin{array}{r}\text { SIMULTANEOUS } \\
\text { processing }\end{array}$ & \multicolumn{2}{|r|}{$\begin{array}{r}\text { MATH } \\
\text { COMPETENCE }\end{array}$} \\
\hline $\begin{array}{c}\text { Age } \\
\text { Range }\end{array}$ & $\mathrm{N}$ & Mean & SD & Mean & SD & Mean & SD & Mean & SD & Mean & SD \\
\hline $8-10$ & 140 & 78.66 & 19.17 & 76.59 & 19.87 & 69.01 & 21.98 & 68.43 & 16.49 & 16.34 & 8.864 \\
\hline $11-13$ & 150 & 96.13 & 20.707 & 95.53 & 18.736 & 95.45 & 17.097 & 83.40 & 15.305 & 27.45 & 10.734 \\
\hline $14-17$ & 160 & 104.69 & 27.57 & 100 & 25.87 & 108.8 & 22.48 & 95.59 & 20.73 & 30.73 & 12.151 \\
\hline
\end{tabular}

1. What is the pattern of improvement in PASS functions with increasing age?

A one way multivariate analysis of variance (MANOVA) was run to determine the effect of age-related difference on PASS functions. The finding indicate that there was a statistically significant difference between age groups on the combined PASS functions development, $F(10,886)=67.6$,

$$
\mathrm{P}<.0005 \text {; Wilks' } \eta=.32 \text {; Portial } \eta^{2}=.43 \text {. }
$$

Table 2: The main result from one-way MANOVA test is contained within the multivariate test table as shown below:

Multivariate Tests

\begin{tabular}{|c|c|c|c|c|c|c|c|}
\hline \multicolumn{2}{|c|}{ Effect } & \multirow{2}{*}{$\begin{array}{r}\text { Value } \\
.987 \\
\end{array}$} & \multirow{2}{*}{$\begin{array}{r}\mathbf{F} \\
6912.886 \\
\end{array}$} & \multirow{2}{*}{$\begin{array}{r}\text { Hypothesis } \\
5.000\end{array}$} & \multirow{2}{*}{$\begin{array}{r}\begin{array}{r}\text { Error } \\
\text { DF }\end{array} \\
443.000\end{array}$} & \multirow{2}{*}{$\begin{array}{r}\text { Sig } \\
.000 \\
\end{array}$} & \multirow{2}{*}{$\begin{array}{r}\begin{array}{r}\text { Partial } \\
\text { Fit a } \\
\text { Squared }\end{array} \\
.987\end{array}$} \\
\hline Intercept & Pillai's Trace & & & & & & \\
\hline & Wilks'Lambda & .013 & 6912.886 & 5.000 & 443.000 & .000 & .987 \\
\hline $\begin{array}{r}\text { Age } \\
\text { Range }\end{array}$ & Pillai's Trace & .782 & 57.040 & 10.000 & 888.000 & .000 & .391 \\
\hline & Wilks' Lambda & .322 & 67.55 & 10.000 & 886.000 & .000 & .433 \\
\hline
\end{tabular}

Follow up multivariate ANOVA to determine how PASS functions differ for different age groups. These results were contained within the table shown below: 
Suzanne M .I.Arafa

Table 3: Test of Between Subjects Effects

\begin{tabular}{|c|c|c|c|c|c|c|c|}
\hline $\begin{array}{r}\text { Sourc } \\
\mathrm{e}\end{array}$ & $\begin{array}{c}\text { Dependent } \\
\text { Variable }\end{array}$ & $\begin{array}{r}\text { Type } 111 \\
\text { sum of } \\
\text { squares }\end{array}$ & DF & $\begin{array}{r}\text { Mean } \\
\text { Square }\end{array}$ & $\mathbf{F}$ & Sig & $\begin{array}{r}\text { Partial } \\
\text { Eta } \\
\text { Squared }\end{array}$ \\
\hline \multirow{4}{*}{$\begin{array}{r}\text { Age } \\
\text { Range }\end{array}$} & Planning_ST & 51879.020 & 2 & 25939.510 & 49.156 & .000 & .180 \\
\hline & SimProce S_ST & 55098.370 & 2 & 27549.185 & 87.300 & .000 & .281 \\
\hline & Attention_ST & 45280.834 & 2 & 22540.417 & 47.368 & .000 & .175 \\
\hline & SuccProce_ST & 120941.641 & 2 & 604479.821 & 141.461 & .000 & .388 \\
\hline \multirow[t]{4}{*}{ Error } & Planning_ST & 235880.511 & 447 & 527.697 & & & \\
\hline & SimProce S_ST & 141059.061 & 447 & 315.568 & & & \\
\hline & Attention_ST & 213652.286 & 447 & 477.969 & & & \\
\hline & SuccProce_ST & 191080.039 & 447 & 427.472 & & & \\
\hline \multirow[t]{4}{*}{ Total } & Planning_ST & 4241619.000 & 450 & & & & \\
\hline & SimProce S_ST & 3301854.000 & 450 & & & & \\
\hline & Attention_ST & 4006160.000 & 450 & & & & \\
\hline & SuccProce_ST & 4118614.000 & 450 & & & & \\
\hline \multirow{4}{*}{$\begin{array}{r}\text { Corre } \\
\text { cted } \\
\text { Total } \\
\end{array}$} & Planning_ST & 287759.531 & 449 & & & & \\
\hline & SimProce S_ST & 196157.431 & 449 & & & & \\
\hline & Attention_ST & 258933.120 & 449 & & & & \\
\hline & SuccProce_ST & 312021.680 & 449 & & & & \\
\hline
\end{tabular}

This table demonstrate that the age related differences has a significant effect for each function, Planning $\left[\mathrm{F}(2,447)=49.156 ; \mathrm{P}<.0005\right.$; partial $\left.\eta^{2}=0.180\right]$, Attention $\left[\mathrm{F}(2,447)=47.368 ; \quad \mathrm{P}<.0005 ;\right.$ partial $\left.\eta^{2}=0.28\right]$. Successive Processing $\left[\mathrm{F}\left(2,447=141.46 ; \quad \mathrm{P}<.0005 ;\right.\right.$ partial $\left.\eta^{2}=0.388\right]$, and Simultaneous Processing $\left[\mathrm{F}\left(2,447=87.3 ; \mathrm{P}<.0005 ;\right.\right.$ partial $\left.\eta^{2}=0.28\right]$.

To determine the precise points of improvement for each function, Post hoc comparisons of adjacent age group were performed (using a Bonferroni correction; $\mathrm{P}<.025)$. Tukey post-hoc tests showed that, there were significant improvements in PASS performance from age group (8 to 10$)$ to (11 to 13 ) to (14 to 17$)$, but performance on Attention improved only until age 13.

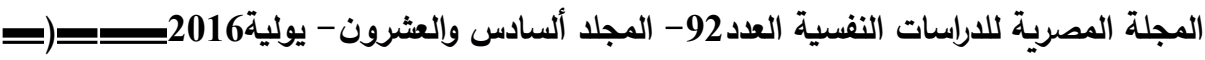


The PAss Processing Developmen and its Relationship Mathematical

Table 4 Tukey Post Hoc Test:

Multiple Comparisons

\begin{tabular}{|c|c|c|c|c|c|c|c|}
\hline Dependent & & & & & & $\begin{array}{c}95 \% \\
\text { Confidence }\end{array}$ & Interval \\
\hline Variable & $\begin{array}{r}\text { Age } \\
\text { Range (l) }\end{array}$ & $\begin{array}{r}\text { Age } \\
\text { Range (j) }\end{array}$ & $\begin{array}{r}\text { Mean } \\
\text { Difference } \\
(1-\mathrm{J})\end{array}$ & $\begin{array}{r}\text { Std. } \\
\text { Error }\end{array}$ & Sig & $\begin{array}{l}\text { Lower } \\
\text { Bound }\end{array}$ & $\begin{array}{l}\text { Upper } \\
\text { Bound }\end{array}$ \\
\hline \multirow[t]{6}{*}{ Planning_ST } & $8-10$ & $11-13$ & -17.47 & 2.699 & .000 & -24.10 & -10.84 \\
\hline & & 14-16 & -26.03 & 2.658 & .000 & -32.56 & -19.50 \\
\hline & $11-13$ & $8-10$ & 17.47 & 2.699 & .000 & 10.84 & 24.10 \\
\hline & & $14-16$ & -8.56 & 2.611 & .005 & -14.97 & -2.15 \\
\hline & $14-16$ & $8-10$ & 26.03 & 2.658 & .000 & 19.50 & 32.56 \\
\hline & & $11-13$ & 8.56 & 2.611 & .005 & 2.15 & 14.97 \\
\hline \multirow[t]{6}{*}{ SimProce_ST } & 8-10 & 11-13 & -14.97 & 2.088 & .000 & -20.10 & -9.84 \\
\hline & & $14-16$ & -27.16 & 2.056 & .000 & -32.21 & -22.11 \\
\hline & $11-13$ & $8-10$ & 14.97 & 2.088 & .000 & 9.84 & 20.10 \\
\hline & & $14-16$ & -12.19 & 2.019 & .000 & -17.15 & -7.23 \\
\hline & $14-16$ & $8-10$ & 27.16 & 2.056 & .000 & 22.11 & 32.21 \\
\hline & & $11-13$ & 12.19 & 2.019 & .000 & 7.23 & 17.15 \\
\hline \multirow[t]{6}{*}{ Attention_ST } & $8-10$ & $11-13$ & -18.93 & 2.569 & .000 & -25.24 & -12.62 \\
\hline & & $14-16$ & -23.48 & 2.530 & .000 & -29.70 & -17.27 \\
\hline & $11-13$ & $8-10$ & 18.93 & 2.569 & .000 & 12.62 & 25.24 \\
\hline & & $14-16$ & -4.55 & 2.485 & .188 & -10.65 & 1.55 \\
\hline & $14-16$ & $8-10$ & 23.48 & 2.530 & .000 & 17.27 & 29.70 \\
\hline & & $11-13$ & 4.55 & 2.485 & .188 & -1.55 & 10.65 \\
\hline \multirow[t]{6}{*}{ SuccProce_ST } & $8-10$ & $11-13$ & -26.43 & 2.430 & .000 & -32.40 & -20.47 \\
\hline & & $14-16$ & -39.79 & 2.393 & .000 & -45.67 & -33.92 \\
\hline & $11-13$ & $8-10$ & 26.43 & 2.430 & .000 & 20.47 & 32.40 \\
\hline & & $14-16$ & -13.36 & 2.350 & .000 & -19.13 & -7.59 \\
\hline & $14-16$ & $8-10$ & 39.79 & 2.393 & .000 & 33.92 & 45.67 \\
\hline & & $11-13$ & 13.36 & 2.350 & .000 & 7.59 & 19.13 \\
\hline
\end{tabular}

To estimate the magnitude of age related differences in PASS, Cohen's d effect sizes were computed between adjacent age groups from (8 to 10) of age, the magnitude was large for all functions, from (11 to 13) the magnitude 
was moderate but between the ages of 14 to 17 , the performance shows less rapid improvements.

Cohen of $.20, .50$, and .80 were interpreted as small, medium, and large, respectively (cohen, 1998).

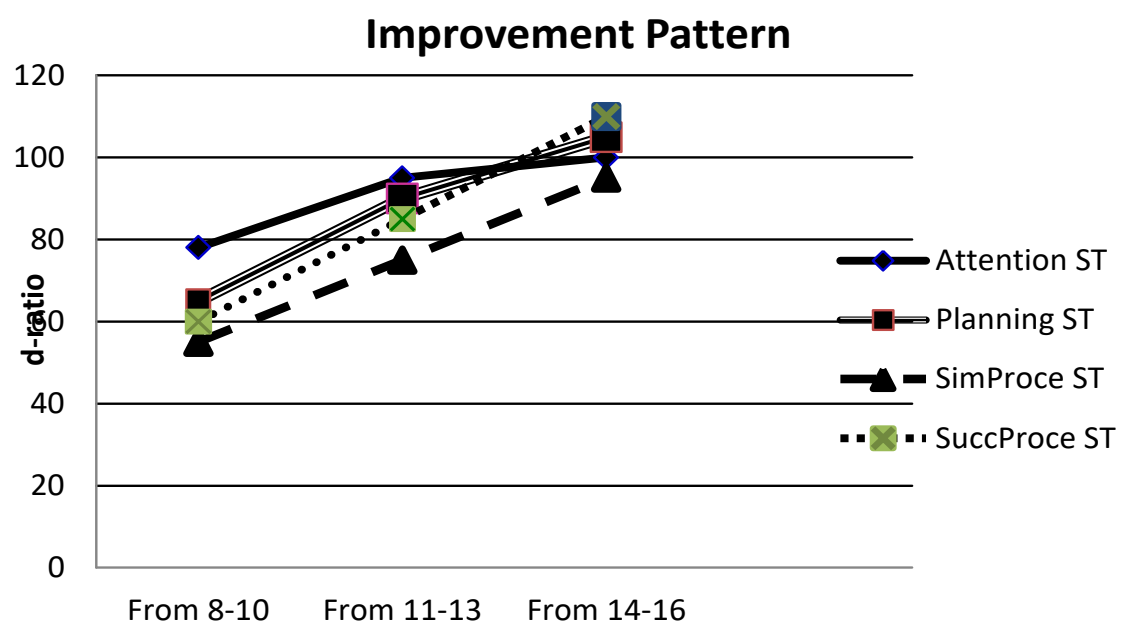

\section{Age comparison}

Figure 1.The rate of change between age groups expressed in $d$ ratios.

2. What is the pattern of improvements in mathematical competence with increasing age?

A one-way ANOVA was conducted to determine if the mathematical competency was different for different age groups. Participants were classified into age groups late childhood ( 8 to10), middle adolescence (11 to 13 ), late adolescence (14 to 17 ) respectively. There were no outliers, as assessed by boxplot; data was normally distributed for each group, as assessed by Shapiro-wilk test $(\mathrm{P}>.05)$; and there was homogeneity of deviation. Mathematical competence score was statistically different between different age groups $\left[\mathrm{F}(3,32)=8.136, \mathrm{P}<.0005\right.$, partial $\left.\eta^{2}=0.48\right]$. Tukey post hoc comparisons of adjacent age groups revealed that there were statistically significant improvement in Math Competence development from age group (8 to 10 ) to (11 to 13 ), $\mathrm{P}<.0001$, and (11 to 13 ) to (14 to 17$), \mathrm{P}<.03$. Thus, the improvement in the magnitude of change developed until middle with less

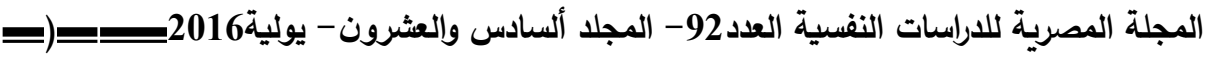




\section{Mathematical Competency}

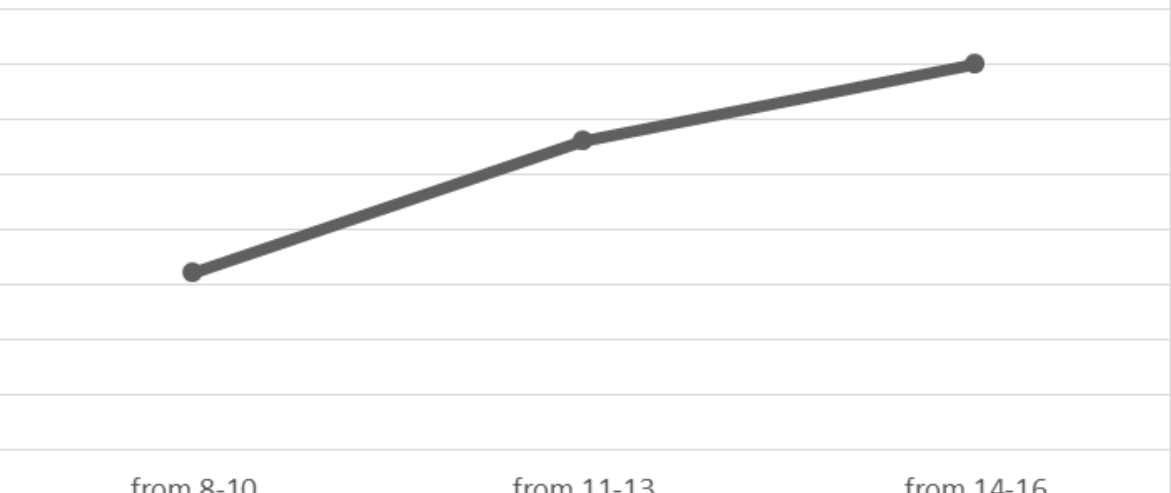

\section{Age comparison}

Figure 2.The rate of change between age groups in mathematical competency.

3. How are PASS functioning and mathematical competency related at each age?

Correlational analyses were used using Pearson product-moment correlation coefficients to examine the pattern of relations between the predictor complex PASS functions and the scores obtained on mathematical competence battery, in each age group.

The review of the correlations for the entire sample showed significant relations among PASS functions and mathematical competence (see table $5)$.

\begin{tabular}{|r|r|r|r|r|}
\hline \multicolumn{1}{|c|}{$\begin{array}{c}\text { AGE } \\
\text { RANGE }\end{array}$} & \multicolumn{1}{|c|}{ PLANNING } & ATTENTION & \multicolumn{1}{c|}{$\begin{array}{c}\text { SIMULTANEOUS } \\
\text { PROCESSING }\end{array}$} & $\begin{array}{c}\text { SUCCESSIVE } \\
\text { PROCESSING }\end{array}$ \\
\hline $8-10$ & $0.23^{* *}$ & $0.78^{*}$ & $0.89 * *$ & $0.45^{*}$ \\
\hline $11-13$ & $0.65^{* *}$ & $0.37 * *$ & $0.91 *$ & $0.15^{* *}$ \\
\hline $14-17$ & $0.94 * *$ & $0.39 * *$ & $0.91 * *$ & $0.24^{*}$ \\
\hline
\end{tabular}

Table 5.Correlations between the predictor variables complex PASS functions and the scores of mathematical competency across different age groups.

$* \mathrm{P}<.05, * * \mathrm{P}<.01$

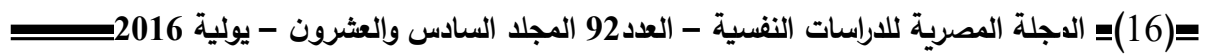


The results of the correlations for the entire sample showed a significant relations among the neurocognitive predictor variables and mathematical competency (See Table5).

The analysis of diverse age groups showed that, $\operatorname{From}(8$ to 10 year): The relations among neurocognitive functions and mathematical competency are mostly significant (Except for Planning), While From (11 to 17year) There is a significant relations with mathematical competency (Except for Successive Processing), To a greater extent, Simultaneous Processing are strong significantly related to Mathematical Proficiency among all age groups.

\section{Discussion}

In the current study 450 participants were chosen randomly with different achievement levels across a wide age range ( 8 to 17) year; using a multiple measures of neurocognitive PASS functions and mathematical proficiency, which is critical to determine how neurocognitive functions are related to the dynamic development of mathematical skills.

Firstly, a fine-grained analysis of developmental patterns across adjacent age groups in the PASS functions were conducted. The results showed that there is a significant age-related differences across different PASS functions, by comparing the magnitude of change across different age groups. Generally, the magnitude of the PASS improvement was large across late childhood group (8 to 10). Then the performance improved to moderate in all neurocognitive tasks until age 14 and diminished further until age 17 on planning. Simultaneous and successive processing, but never improved on attention.

This finding supports the previous studies which have shown that complex frontal lope begins to develop rapidly during childhood; with the maturation of frontal functioning and continuous during middle childhood, then decreased gradually thereafter through adolescence and early adulthood (Romine \& Reynolds, 2005; Anderson, 2002; Davidson, Amso, Anderson \& Dimond, 2006; Luciana, Conklin, Hooper \& Yarger, 2005; Altemeier et al., 2006).

Moreover, the result revealed that there is no significant improvement in attention subtests score after age 14. This finding is in accordance with previous developmental studies in attention (inhibition/updating) which reported that rapid early improvements in attention was followed by slower improvements through middle adolescence, along with greater brain localization throughout childhood and adolescence. This may be due to brain maturation, increased ability to handle task complexity and increased ability to use rules and emerging Meta cognition (e.g., Miyake et al., 2000; Garon et al., 2008; Carlson, 2005; Gerstadt et al., 1994). Although, the improvement

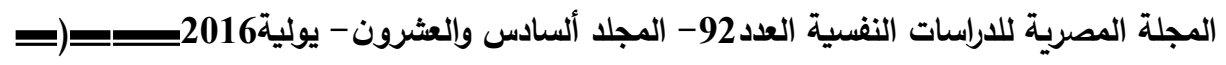


may continue into middle adolescence.

Secondly, the present study was to investigate mathematical competency improvement given the changing nature of actual performance across wide range ( 8 to17) years. The result reveal that the differences on mathematical competence performance based on different age groups in childhood and adolescence $(\mathrm{P}<.0005)$ and by comparing the magnitude of change. The finding showed that performance development improved over a wide age range ( 8 to 17$)$ years and the improvement slowed from (14 to 17) age group. These findings until age 14, support the conclusion in which the individual differences in mathematical achievement increased across age (Muthen \& Khoo, 1998; Williamson et al., 1991). But we found that the individual difference in performance slowed rather than increased rapidly from age 14 to 17. This may be, due to the memorized systematic instruction children receive at early school which affect their ability to acquire effective competencies and to process their accumulated mathematical knowledge efficiently in complex real situations after that. Or maybe, to the increasing difficulty of the target operations to be learned (Parrila, Aunola, Leskinen, Nurmi \& Kirby, 2005; Phillips, Norris, Osmond \& Maynard, 2002) which suggests that, initial level of performance predicts positive subsequent growth and increasing inter individual differences in performance over time.

Thirdly, the study examines Correlations Patterns between the neurocognitive predictors of mathematical competence performance within each age group. The pattern of relations across different ages were studied. From (8 to 10). We observed a strong positive correlation between Attention associated with Simultaneous processing and Mathematical Competency improvement and moderate with Successive processing; but weak correlation between Planning and Math Performance were reported. These results could be interpreted as the role of attentional resources may be critically important during the early phases of development when basic skills are to be learned and automatized. While weak correlation with planning as it may be less important in the acquisition of fundamental processes in math skills at childhood (Geary et al., 1999). This result contradict the finding of (Altemeier et al., 2006) who posed that Planning (Executive Function) may be more important earlier in schooling.

From age (11 to 13). The pattern of relation showed that strong positive correlation between Simultaneous processing, Planning and Math Competence were more moderate between attention and math performance, but weak correlation with successive processing. These finding confirm the results of (Naglieri \& Das, 1987) and extend them to a wide age range, in which the students during (11 to 13 ) need to be more recognized for using

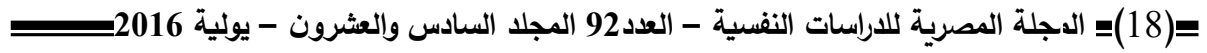


effective strategies and flexibly applying the accumulated mathematical cognition which should be more automatically applied to new situations. Such recognition would mean more activation of simultaneous processing than of successive processing.

Finally, from age (14 to 17), the pattern of relations showed high correlation between mathematical performance, Simultaneous processing and planning more moderate with attention, but weak correlated with Successive processing.

This finding extend the results of previous studies (e.g. De Smedt et al., 2009; Hecht et al., 2001), in which the successive function become less important than simultaneous which support the result of (Naglieri \& Das, 1997) and it extends them to wide age range. Importantly, according to above results, we suggest that the decreasing rate of improvement in mathematical performance from age (14 to 17) may be associated with growth analysis on planning which diminished significantly after age 14 and never improved on attention. Previous results have shown that problems with executive control and attentional allocation are related to learning disabilities in mathematics (Acherman et al., 2001; Geary et al., 1999; Mclean \& Hitch, 1999). The present study contributes to these findings by showing that attentional resources were related to the rate of growth in math performance as it affects how students initiate and direct their processing of information in different tasks. Also, how they comprehended it, and how the executive function (Planning) plays a dominant role in their acquiring math competencies due to difficulties to retrieve representations to be remembered when doing tasks; and also to attend and in carrying out new instruction is vital thus inhibiting irrelevant information, while staying focused on their target and monitoring progress, as well as switching to more appropriate strategies while confronting with a new situations.

Summing up, the findings of the study shows correlations in mathematical competence to underlying PASS neurocognitive functions within each age group. According to our cross-sectionalstudy, along the lines of other works (Kroesbergen et al., 2003; Naglieri \& Johnson, 2000). The results obtained recommend immediate educational training to promote the improvement of neurocognitive functioning and acquiring mathematical competencies using PASS processing with students of diverse characteristic and different ages.

An apparent limitation of this study is the cross-sectional treatment of the data. Along the lines of some recent works, future work should be performed in doing studies using longitudinal analysis of the data as extensively as possible.

\section{Conclusion:}

Practiced in mathematical knowledge through effective use of activating

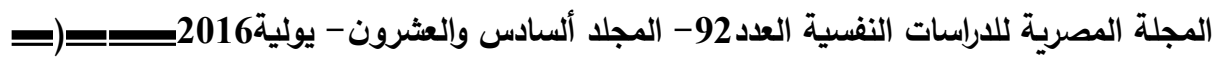


mathematical competencies, maybe associate with the changing pattern of significant neurocognitive predictor.

• فؤاد أبو حطب، ( 2010 ) القدرات العقلية ، ط 5 ، القاهرة : مكتبة الأنجلو المصرية.

• صفاء بحيرى(2001):أثر برنامج تدرببى لذوى صعوبات التعلم فى مجال الرياضيات فى ضوء

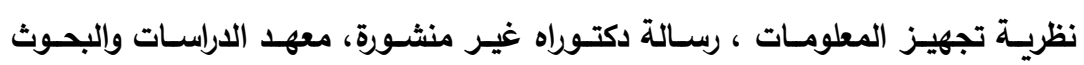

التربويةة، جامعة القاهرة.

• عادل العدل (2000): أثر الأسلوب المعرفى واستراتيجية تجهيز المعلومات على الذاكرة العاملة ، مجلة كلية التربية، جامعة عين شمس، (24) 3 ، 243 - 2323.

• عبد الوهاب كامل (1993):النموذج الكلى لوظائف المخ ، المجلة المصرية للاراسات النفسية ، . $52-29$ (4)

• علاء الدين السعيد عبد الجواد (2010):فعالية التدريب على العمليات المعرفية وفق نموذج PASS الرابع الابتدائى ذوى صعوبات التعلم ، المجلة المصرية للدراسـات النفسية، (87)، مجلد

$$
.305-250-25
$$

• فؤاد أبو حطب ، أمـال صـادق (2010) :منـاهج البحث وطرق التحليل الإحصـائى فى العلوم النفسية والتربوية والاجتماعية ، مكتبة الإنجلو المصرية.

• صفاء الأعسر (1998) : تعليم من أجل التفكير، القاهرة ، دار قباء للطباعة والنشر والتوزيع.

• أيمن الايب محمد عبد الرحيم (2001) : استخدام نموذج PASS فى التثخيص الفارقى لعينة من ذوى الحاجات الخاصة المعاقين ذهنيا القابلين لتعلم، رسالة ماجستير غير منشورة ، كلية البنات ، جامعة عين شمس.

• رشا محمد عبد الله (2002): القيمة التشخيصية لنموذج التقدير المعرفى CAS كما تظهر فى العلاقة بين نموذج PASS والتحصيل الاراسسى ، رسـالة ماجستير غير منشسورة، كلية

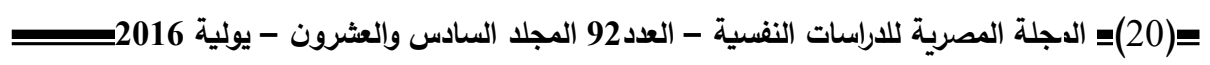




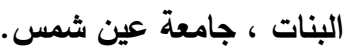

• محمد رياض(1997):أثر برنامج تدريبي لتنمية المعالجة المعرفية المتابعة والمتزامنة علي

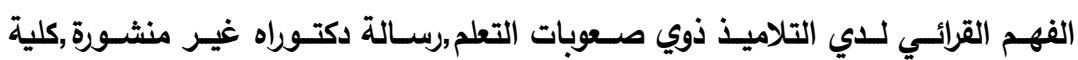

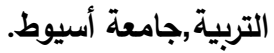

• فادية علوان(1998):دراسة تحليلية نقاية عن انعكاسات مفاهيم الذكاء الحديثة في مجال النمو

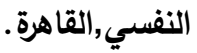

Altemeier, L., Jones, J., Abbott, R.D., \& Berninger, V. W. (2006). Executive functions in becoming writing readers and reading writers: note taking and report writing in third and fifth graders. Developmental Neuropsychology, 29 (1), 161-173. (PubMed: 16390292).

Anderson, P. (2002). Assessment and development of executive function (EF) during childhood. Child Neuropsychology, 8 (2), 71-82 (PubMed: 12638061).

Carlson, S. M. (2005). Developmentally sensitive measures of executive function in preschool children. Developmental Neuropsychology. 28(2), 595-616. (PubMed: 16144429).

Das, J. P., Naglieri, J. A. \& Kirby, J.R. (1994). Assessment of cognitive processes. The PASS theory of intelligence. New York: Allyn \& Bacon.

Das, J. P., \& Naglieri, J. A. (2001). The Das-Naglieri Cognitive Assessment System in theory and practice. In J.J. Andrews, D.H. Saklofske, \& H.L. Janzen (Eds.). Handbook of psychoeducational assessment: Ability, achievement, and behavior in children. (pp. 34-64). San Diego: Academic Press.

Davidson, M.C., Amso, D., Anderson, L.C., Diamond, A. (2006). Development of cognitive control and executive functions from 4 to 13 years: evidence from manipulations of memory, inhibition and task switching.

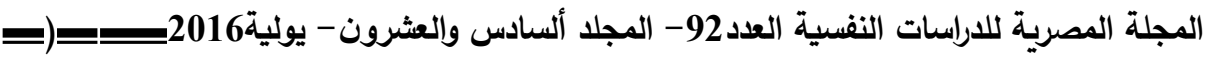


Neuropsychologia, 44, (11), 2037-2078. (Pub Med: 16580701)

De Smedt, B., Janssen, R., Bouwens, K. Verschaffel, L., Boets, B., \& Ghesquiere, P. (2009). Working memory and individual differences in mathematics achievement: a longitudinal study from first to second grade. Journal of Experimental child Psychology, 103, 186-201.

Garon, N., Bryson, S.E., Smith, I.M. (2008). Executive function in preschoolers: a review using an integrative framework. Psychological Bulletin. 134,(1), 31-60. (PubMed: 18193994).

Geary, D. C., Hoard, M. K. \& Hamson, C. O. (1999). Numerical and arithmetical cognition: patterns of functions and deficits in children at risk for a mathematical disability. Journal of Experimental Child Psychology, 74, 213-239.

Gerstadt, C.L., Hong, Y.J., Diamond, A. (1994). The relationship between cognition and action: performance of children $3 \frac{1}{2}-7$ years old on a stroop-like day-night test. Cognition, 53 (2), 129-153. (Pub Med: 7805351)

Goldberg, E. (2001). The executive brain: frontal lobes and the civilized mind. New York: Oxford University Press.

Hecht, S. A., Torgesen, J. K. Wagner, R.K., \& Rashotte, C. A. (2001). The relations between phonological processing abilities and emerging individual differences in mathematical commutation skills: a longitudinal study from second to fifth grades. Journal of Experimental Child Psychology, 79 (2), 192-227.

Joseph, L.M., \& Hunter, A. D. (2001). Differential application of a cue card strategy for solving fraction problems: exploring instructional utility of the cognitive assessment system. Child Study Journal, 31(2), 123-136.

Krajewski, K., \& Schneider, W. (2009). Exploring the impact of phonological awareness, visual-spatial working memory, and preschool quantity-number competencies on

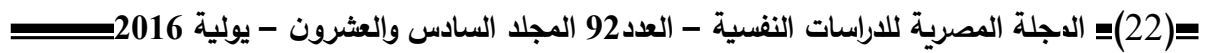


mathematics achievement in elementary school: findings from a 3 year longitudinal study. Journal of Experimental Child Psychology, 103, 516-531.

Kirby, J. R., \& Ashman, A.F. (1984). Planning skills and mathematics achievement: Implications regarding learning disability. Journal of Psychoeducational Assessment, 2 (1), 9-22.

Kirby, J. R., \& Williams, N. H. (1991). Learning problems: A cognitive approach. Toronto: Kagan and Woo Ltd.

Kroesbergen, E. H., Van Luit, J. E.H., \& Naglieri, J. A. (2003). Mathematics learning difficulties and PASS cognitive processes. Journal of Learning Disabilities, 36 (6), 574582.

Kroesbergen, E. H., Van luit, J. E.H., Naglieri, J. A, Taddei, S, \& Franchi, E. (2010). PASS processes and early mathematics skills in Dutch and Italian kindergartners. Journal of Psychoeducational Assessment, 28 (6), 585593.

Luciana, M., Conklin, H.M., Hooper, C.J., Yarger, R.S. (2005). The development of nonverbal working memory and executive control processes in adolescents. Child Development. 76 (3), 697-712, (Pub Med: 15892787).

Luria, A. R. (1980). Higher cortical functions in man ( $2^{\text {nd }}$ Ed.) New York: Basic Books.

Luria, A. R. (1973). The working brain: an introduction to neuropsychology. New York: Basic Books.

Luria, A. R. (1966). Human Brain and Psychological Process. New York: Harper \& Row.

Mayer, R. E. (1992). Cognition and instruction: Their historic meeting within educational psychology. Journal of Educational Psychology, 84 (4), 405-412.

Mclean, J. F., \& Hitch, G. J. (1999). Working memory impairments in children with specific arithmetic learning difficulties.

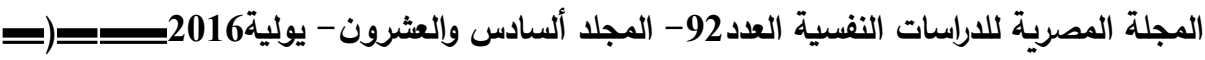


Journal of Experimental Child Psychology, 74 (3), 240260.

Miyake, A., Friedman, N. P., Emerson, M. J., Witzki. A.H., Howerter, A., Wager, T. D. (2000). The unity and diversity of executive functions and analysis. Cognitive Psychology, 41(1), 49-100. (Pub Med: 10945922).

Muthen, B. O., \& Khoo, S. T. (1998). Longitudinal studies of achievement growth using latent variable modeling. Learning and Individual Differences, 10 (2), 73-102.

Naglieri, J. A., \& Das, J. P.(1997a). Cognitive Assessment System. Administration and scoring manual. Interpretive handbook. Austin, TX. ProEd.

Naglieri, J. A., \& Das, J.P. (1997b) Cognitive Assessment System interpretive handbook. Chicago: Riverside Publishing Company.

Naglieri, J. A.(2005). The Cognitive Assessment System. In D.P. Flanagan and P.L. Harrison (Eds.), Contemporary intellectual assessment (2nd ed., 441-460).Austin, TX: ProEd

Naglieri, J. A., \& Das, J. P. (1987). Construct and criterion related validity of planning, simultaneous and successive cognitive processing tasks. Journal of Psych educational Assessment, 4, 353-363.

Naglieri, J. A., \& Johnson, D. (2000). Effectiveness of a cognitive strategy intervention to improve math calculation based on the PASS theory. Journal of Learning Disabilities, 33, 591-597. (Pub Med: 15495400)

Niss, M. A. (2003). Mathematical competencies and the learning of mathematics: the Danish Kom project. In A. Gagatis \& S. Papastavridis (eds.), $3{ }^{\text {rd }}$ Mediterranean Conference on mathematical education - Athens, B (116-124). Athens: Hellnic Mathematical Society.

Organisation for Economic Co-operation and Development (OECD).

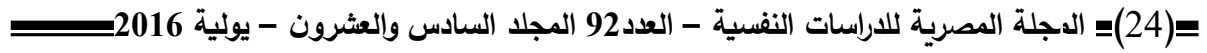


(2000). Measuring student knowledge and skills: The PISA 2000 Assessment of reading, mathematical and scientific literacy. Paris: PISA, OECD Publishing. doi: 10.1787/9789264181564-en.

Parrila, R., Aunola, K., Leskinen, E., Nurmi, J. E., \& Kirby, J. (2005). Development of individual differences in reading: results from two longitudinal studies in English and Finish. Journal of Educational Psychology, 97 (3), 299319.

Phillips, L. M., Norris, S. P., Osmond, W. C. \& Maynard, A. M. (2002). Relative reaching achievement: a longitudinal study of 187 children from first through sixth grades. Journal of Educational Psychology, 94, 3-13.

Rico, L. (2006). Marco Teorico de evaluacion en PISA sobre matematicasy resolucion de prodlemas. Revista de Educacion, Extraordinario, 2006, 275-294.

Riccio, C. A., Sullivan, J.R., \& Cohen, M.J. (2010). Neuropsychological assessment and intervention for childhood and adolescent disorders. Hoboken, N.J.: Wiley

Romine, C. B, Reynolds, C.R. (2005). A model of the development of frontal lobe function: findings from a meta-analysis. Applied Neuropsychology, 12, 190-201. (Pub Med: 16422660)

Slater, A., Bremner, G. (2003). An introduction to developmental psychology. London: Blackwell Publishing.

Soto-Calvo, E., Simmons, F. R., Willis, C., \& Adam, A. (2015). Identifying the Cognitive Predictors of Early Counting and Calculation Skills: Evidence from Longitudinal Study. Journal of Experimental Child Psychology, 140, 16-37.

Turner, R. Stacey, K. (2015). Assessing mathematical literacy. Switzerland: Springer International Publishing.

Vernon, P. G., Miller, K.M., Izard, J. F. (2013). Mathematics

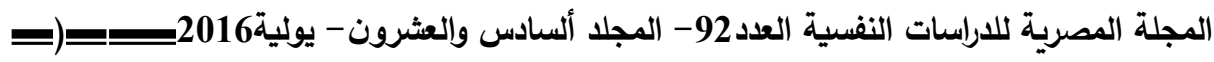


competency test. British Library: Hodder Education.

Williamson, G. L., Appelbaum, M., \& Epanchin, A. (1991). Longitudinal analyses of academic achievement. Journal of EducationMeasurement, 28, 61-76. 
نمو وظائف PASS و علاقتها بالكفاءة الرياضية (تقييم نفسعصبي) م.م. مسوزان محمد إبراهيم عرفه

مدرس مساعد بقسم علم النفس التربوي

كلية التربية- جامعة حلوان

أ.د.محمد عبد القادر عبد النفار

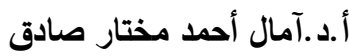

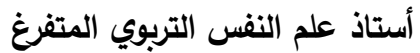

أستاذ علم النفس التربوي المتفرغ احتل

كلية التربية- جامعة حلوان

كلية التربية- جامعة حلوان

ملخص البحث

أن دراسة العلاقة بين نمو وظائف المخ لدي الأطفال والعملية التعليمية يعتبر هدفاً رئيسياً لعلم

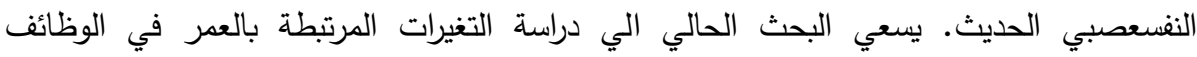
النفسعبية المعقدة في ضوء نظرية PASS والكفاءة الرياضية لدي طلاب التعليم العام لعينة ممثلة

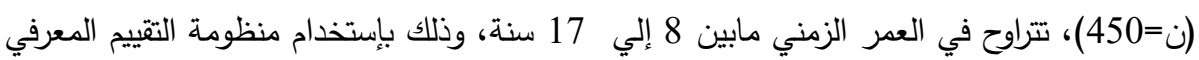

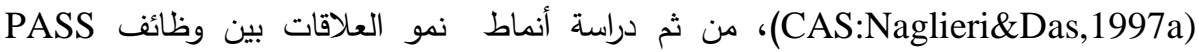

والكفاءة الرياضية، بإستخدام بطارية الكفاءة الرياضية (Vernon,Miller, and Izard,2013 ).

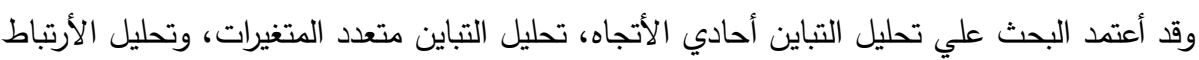

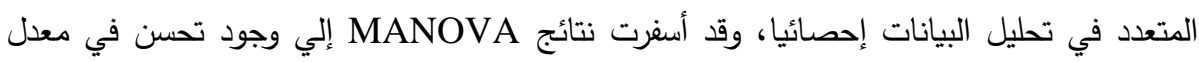

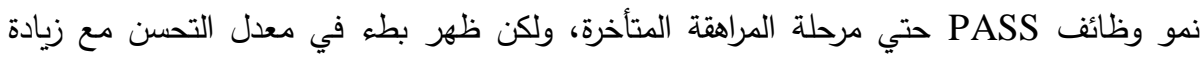
العمر، بينما توصلت النتائج إلي عدم وجود أي تحسن في وظيفة الأنتباه ما بعد عمر (13 لسنة). إضافة لذلك، قد أظهرت نتائج تحليل ANOVA تحسن معدل النمو في أداء الكفاءة الرياضية حتي عمر (14 سنة)، مع وجود بطء في معدل النمو حتي عمر (17 اسنة).

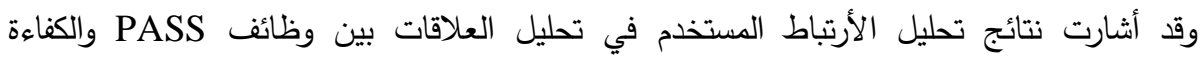
الرياضية إلي وجود علاقة قوية موجبة ذات دلالة إحصائية مابين عمليتي الأنتباه والمعالجة المتزامنة الكائة والكفاءة الرياضية وذلك من عمر (8إلي 10سنين)،بينما ظهرت وجود علاقة متوسطة موجبة ذات دلالة إحصائية بين المعالجة المتتابعة والكفاءة الرياضية، مع عدم وجود علاقة ذات دلالالة إحصائية بين التخطيط والكفاءة الرياضية في هذه المرحلة العمرية.

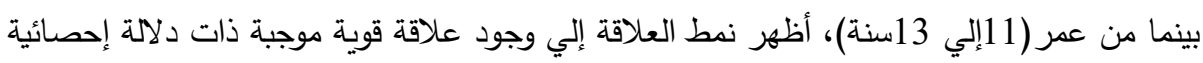
مابين عمليتي المتزامنة والتخطيط والكفاءة الرياضية، مع وجود علاقة متوسطة ذاتئة التات دلاللة إحصائية

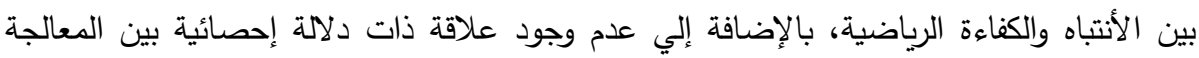

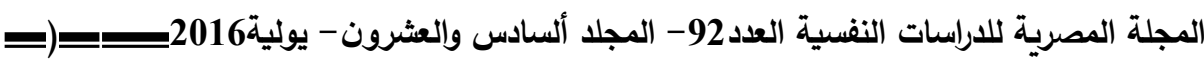


المتتابعة والكفاءة الرياضية.

ومن عمر (14 إلي 17سنة)، فقد أسفرت النتائج إلي وجود علاقة موجبة قوية ذات دلالة إحصائية مابين المعالجة المتزامنة والتخطيط مع الكفاءة الرياضية، وعلاقة متوسطة ذات دلالة إحصائية مع الانتباه، وأخيرا ظهر عدم وجود

علاقة ذات دلالة إحصائية بين المعالجة المتتابعة والكفاءة الرياضية في هذه المرحلة العمرية. وبشكل عام، توصلت نتائج البحث إلي قوة الأرتباط بين المعالجة المتزامنة ونمو الكفاءة الرياضية بكل

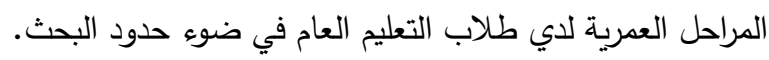
وتوصي نتائج البحث بأهمية تطبيق برامج تدريبية تعتمد علي تتمية وظائف PASS النفسعصبية،

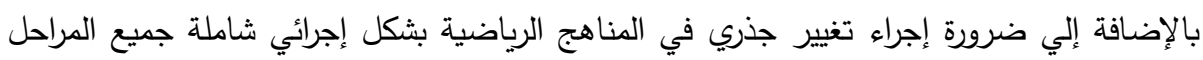

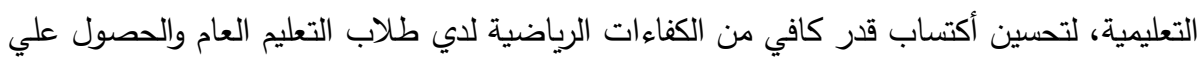
مخرجات إيجابية لنمو التقكير الرياضي والمعرفي بشكل عام، والذي بدوره يؤثرعلي تعزيز قدرات الطالب وتحسين نمو العملية التعليمية لديهم. 